\title{
Penatalaksanaan Fraktur Kompleks Zygomatikomaksilaris Sinistra dengan Miniplate Osteosynthesis
}

\author{
Pedro Bernado*, Prihartiningsih***, dan Cahya Yustisia Hasan** \\ *Program Studi Ilmu Bedah Mulut dan Maksilofasial PPDGS Fakultas kedokteran Gigi, Universitas Gadjah Mada \\ **Bagian Ilmu Bedah Mulut dan Maksilofasial, Fakultas Kedokteran Gigi, Universitas Gadjah Mada \\ ***Bagian Bedah Bedah Mulut RSUP Dr. Sardjito \\ *Jl. Denta No. 1 Sekip Utara No 1 Yogyakarta, e-mail: pedrobernado.pb@gmail.com
}

\begin{abstract}
ABSTRAK
Wajah terletak lebih ke anterior secara anatomis oleh sebab itu mudah mendapatkan trauma. Os Zigoma merupakan tulang yang menonjol pada wajah dan akan menahan gaya bentur terbesar pada wajah. Tulisan ini melaporkan penatalaksanan fraktur kompleks zigomatikomaksilaris sinistra dengan miniplate osteosynthesis.Seorang laki-laki 22 tahun dirujuk ke Bagian Bedah Mulut RSUP Dr Sardjito dengan riwayat kecelakaan lalulintas tiga minggu sebelum masuk RS. Pasien mengeluh daerah pipi kiri terasa tebal dan dirasa lebih datar dari pipi kanan. Pemeriksaan klinis terdapat parestesi nervus infraorbita sinistra, displace tulang daerah infraorbital rim sinistra, diskontinuitas regio sinus maksilaris sinistra. Radiografis CT axial dan koronal serta CT Scan 3D tampak fraktur melibatkan infraorbital rim sinistra, fraktur sinus maksila sinistra, fraktur pada sutura zigomaticofrontalis dan pada sutura zigomatikotemporalis. Penatalaksanaannya dilakukan open reduction internal fixation (ORIF) fraktur kompleks zigomatikomaksilaris dengan miniplate osteosynthesis di bawah anestesi umum. Pasca operasi gejala parestesi berangsurangsur berkurang, defek infraorbital rim terkoreksi dan pipi kiri tampak kembali prominen. Prognosis kasus ini dubia ad bonam. ORIF dengan miniplate osteosynthesis dapat memulihkan deformitas wajah dengan hasil malar eminensia kembali prominen dan membuat kondisi dekompresi nervus infraorbita sinistra yang mendukung proses pemulihan sensorisnya.
\end{abstract}

Maj Ked Gi; Desember 2013; 20(2): 161-169

Kata Kunci: fraktur kompleks zigomatikomaksilaris, miniplate osteosynthesis, ORIF

ABSTRACT: Management of Zygomaticomaxillaris Sinistra Complex Fractures with Osteosynthesis Miniplate. Face lies in a prominent position so that this area is often susceptible to trauma. Os zygomaticum is an area that holds the heaviest impact on facial trauma. This paper reports one case about zygomaticomaxillary complex fractures management with miniplate osteosynthesis. A 22 years old man was referred to the Department of Oral Surgery Dr Sardjito Hospital with a history of traffic accident three weeks before admission. He felt that his left cheek was thick and flatter than the right one. Clinical examination found that the left infraorbita nerve was paresthesized, the bone on the left infraorbital rim region was displaced and the left maxillary sinus region was discontinued. Radiography examination using CT axial and coronal, and 3D CT scan showed both of the left infraorbital rim and maxillary sinus were fractured, as well as the zygomaticotemporalis suture and the zygomaticofrontalis suture. An Open Reduction Internal Fixation (ORIF) of the zygomaticomaxillary complex fractures with miniplate osteosynthesis was performed under general anesthesia. The result showed that the postoperative paresthesia symptoms were gradually diminished, the infraorbital rim defects were corrected and the prominent left cheek was recontructed. The prognosis was dubia ad bonam. It can be concluded that ORIF with miniplate osteosynthesis reconstructs the facial deformity, recovers the malar eminence prominency. The nerves decompression will favor the recovery process of the left infraorbita sensory.

Maj Ked Gi; Desember 2013; 20(2): 161-169.

Keywords: zygomaticomaxillary complex fractures, miniplate osteosynthesis, ORIF 


\section{PENDAHULUAN}

Pasien dengan riwayat cedera kepala erat kaitannya dengan trauma yang terjadi pada daerah wajah. ${ }^{18}$ Letak anatomis wajah lebih ke anterior, oleh sebab itu membuatnya lebih mudah mendapatkan trauma. $^{2}$ Os Zigoma merupakan tulang yang menonjol pada wajah dan akan mendapatkan gaya bentur terkuat pada wajah yang mengalami trauma. ${ }^{2}$ Tulang zigomatik sangat erat hubungannya dengan tulang maksila, tulang dahi serta tulang temporal, dan karena tulang tulang tersebut biasanya terlibat bila tulang zigomatik mengalami fraktur sehingga lebih tepat disebut fraktur kompleks zigomatik. Beberapa penulis menganggap sebagai fraktur komplekszigomatikomaksilar. ${ }^{3}$ Sejarahnya pernah digunakan istilah fraktur "tripot" untuk mendiskripsikan fraktur yang melibatkan dinding orbita lateral, sutura zigomatikomaksilaris dan sutura zigomatikotemporalis, kemudian digunakan istilah yang lebih tepat yaitu fraktur kompleks zigomatikomaksilaris (Zigomaticomaxillary Complex Fractures/ZMC fractures. $)^{4}$

Fraktur kompleks zigomatik dapat terjadi sebagai fraktur yang berdiri sendiri atau bersama dengan fraktur sepertiga tengah tulang fasial lain dan merupakan fraktur yang paling umum di dalam kelompok ini. Pada penelitian sebelumnya ditemukan insidensi fraktur zigomatikus 22,2\% hingga $51,19 \% .^{3}$ Dingman $^{5}$ mengklasifikasikan jenis fraktur berdasarkan kestabilan perawatan dengan reduksi tertutup, dan menyatakan bahwa fraktur dengan lateral displacement dan atau dengan comminuted kurang stabil jika dirawat dengan reduksi tertutup.

Fraktur ZMC dapat ditandai dari adanya pembengkakan yang disertai dengan hematom periorbita dan perdarahan subkonjungtiva, kontur muka tidak simetris, krepitasi, perdarahan hidung pada sisi yang mengalami fraktur. Pada palpasi, diastase tulang dapat dirasakan pada daerah infraorbita, pada tepi orbita dan pada daerah crista zigomaticoalveolaris. Parestesi, hipoestesi atau anestesi dapat menyertai pada bagian pipi, hidung dan bibir atas yang merupakan daerah persarafan nervus infraorbitalis. Gangguan membuka mulut dapat terjadi akibat rotasi dan pergeseran dari prosesus zigomatikus ke kaudal. Jika melibatkan fraktur orbita maka dapat ditemui gangguan penglihatan berupa diplopia. Selain itu juga dapat disertai enoptalmus dan eksoptalmus. ${ }^{5}$

Jika tanda dan gejala suatu trauma mengindikasikan adanya injuri zigomatik, langkah yang terbaik untuk memastikan dan mengevaluasi kerusakan adalah melalui pemeriksaan radiografis khusus $C T$ scan. Plain radiografi menjadi alternatif sekunder. $C T$ scan diambil pada potongan dengan interval $3 \mathrm{~mm}$ pada potongan axial dan koronal. Potongan axial untukmengevaluasiarkus zigomatikus, dinding orbita dan sinus maksilaris. Potongan koronal mengevaluasi sutura frontozigomatikus, infraorbital rim dan lateral orbital rim. ${ }^{4}$

Pada fraktur tanpa displacement dan asimtomatik cukup dengan menginstrusikan diet lunak 3-4 minggu. Pada fraktur dengan displacement, perubahan kontur muka, gangguan membuka mulut, parestesi, dan gangguan penglihatan perlu dilakukan perbaikan fraktur dengan operasi. Akses operasi didapat dari insisi subsiliar, infraorbita, lateroorbita, transkonjungtiva dan juga intraoral (insisi paramarginal). Perlu dilakukan pemasangan miniplate atau mikroplatedengan diameter sekrup 2 atau 1,3 mm untuk stabilisasi dan fiksasi. Pemasangan miniplate minimal pada dua lokasi, meliputi daerah infraorbita, latero-orbita, dan intraoral pada krista zigomatikoalveolaris. ${ }^{6}$ Tujuan dari artikel ini adalah untuk memaparkan metode tata cara fraktur kompleks zygomatik-omaksilaris sinistra menggunakan miniplate osteosynthesis.

\section{LAPORAN KASUS}

Seorang laki-laki 22 tahun di rujuk ke Bagian Bedah Mulut RSUP Dr Sardjito tiga minggu pasca kecelakaan lalulintas dengan keluhan utama pipi kiri dan daerah bawah mata kiri terasa tebal, pipi kiri dirasakan lebih datar daripada pipi kanan. Dua minggu sebelum masuk rumah sakit pasien mengalami kecelakaan lalu lintas kendaraan bermotor roda dua, riwayat pingsan positif, ada riwayat perdarahan hidung kiri. Pasien dirawat inap selama satu minggu dengan diagnosis cedera kepala ringan dan kemudian perawatan rawat jalan selama 
satu minggu. Pasien datang di poli Bedah Mulut RSUP dr Sardjito dengan kondisi mual (-), muntah $(-)$, pusing (-) , VAS: 3, CCS:15, pipi kiri dan bawah mata kiri terasa tebal, tidak ada keluhan penglihatan. Kondisi sistemik pasien baik.

Pemeriksaan reflek mandibula, mandibular range of motion, membuka mulut dan tutup mulut dan pemeriksaan TMJ dalam batas normal. Palpasi basis mandibula kanan dan kiri tidak ditemukan diskontinuitas. Inspeksi muka tampak asimetri pada sepertiga wajah bagian tengah. Pipi kiri terkesan tidak prominent dibanding sisi kanan dan terasa tebal di pipi kiri (Gambar 2). Pemeriksaan mata tampak ketinggian bola mata kanan dan kiri segaris dengan reflek berkedip dalam batas normal, terdapat ekimosis sirkumorbital kanan dan kiri, ekimosis lebih dominan pada mata kiri (Gambar 1), tes diplopia negatif, tes otot-otot bola mata dalam batas normal. Tes reflek kornea positif dan tampak kelopak mata kiri bagian bawah tampak lebih ke inferior dibandingkan dengan mata kanan.

Pemeriksaan neurosensoris klinis, light touch, dengan usapan lembut menggunakan cotton butt dapat diperoleh daerah yang mengalami defisit neurologis (parestesi) daerah inferior mata kiri, daerah pipi kiri, daerah hidung kiri, daerah bibir atas kiri. Pemeriksaan pin pricktest menggunakan ujung sonde runcing pada daerah yang defisit neurologis didapatkan hasil yang positif (nyeri masih dirasakan).

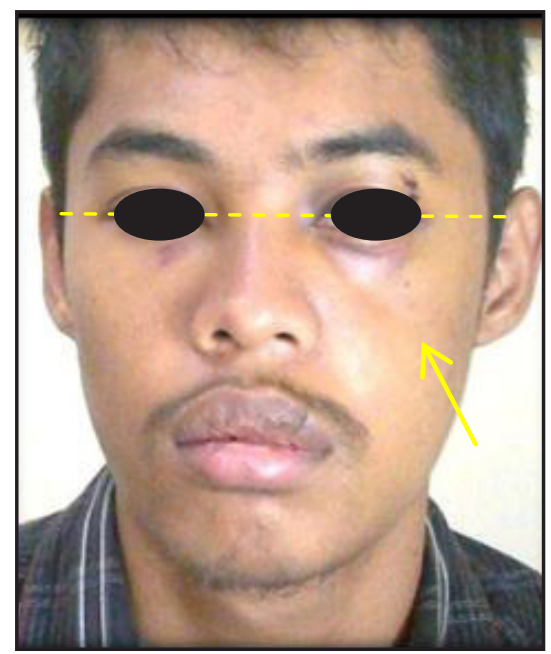

Gambar 1. Foto klinis pasien ekstraoral dengan kesan ekimosis sirkumorbital
Pemeriksaan intraoral hubungan rahang atas dan rahang bawah maloklusi angel klas I kanan dan kiri.

Pemeriksaan radiologis panoramik tampak fraktur dinding sinus maksilaris sinistra. Hasil CT scan axial tampak fraktur depresed zigoma sinistra ke sinus maxilaris sinistra dengan hematosinus sinistra (Gambar 3). CT scan koronal tampak dasar orbita utuh dan fraktur sutura zigomatikofrontalis (Gambar 4). 3D CT scan dengan kesan fraktur depresed sepanjang sutura zigomatikomaksila hingga infra orbital rim sinistra ke arah posterior, fraktur dinding sinus maksilaris sinistra, fraktur non displace pada sutura zigomatikofrontalis dan zigomatikotemporalis (Gambar 5). Pasien didiagnosis mengalami fraktur kompleks zigo-matikomaksilaris sinistra.

Persiapan dilakukan sebelum operasi dengan pemasangan interdental wiring menggunakan arch bar dari regio 16-26 dan 36-46 dengan anetesi lokal satu hari sebelum tindakan operasi. Profilaksis antibiotik injeksi IV Ampicillin 2 gram diberikan satu jam sebelum operasi.

Pasien dalam stadium teranestesi dengan ET oral kanan dilakukan tindakan antiseptik ekstraoral dan dilanjutkan di intraoral dengan larutan iodin povidon $10 \%$, pemasangan duk steril dan oropharing pack. Proteksi mata pasien dengan subkutan matres horisontal kelopak mata atas dan bawah dengan benang Silk 3.0 (tarsoraphy)

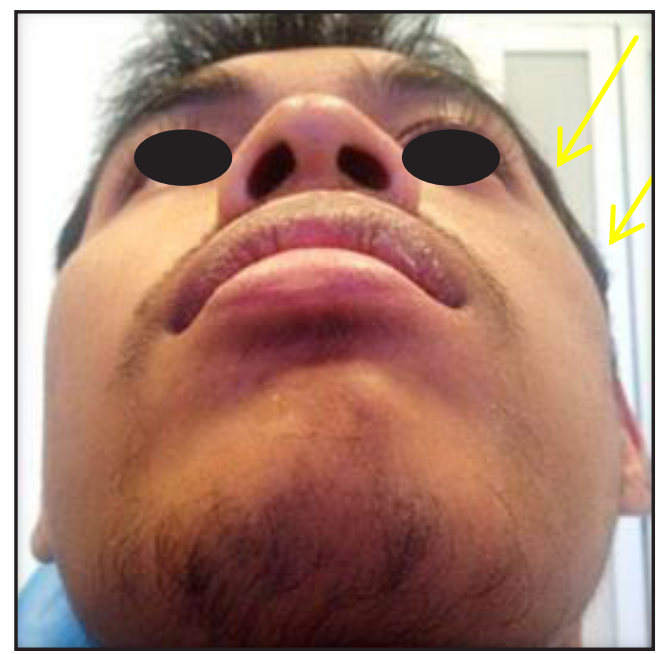

Gambar 2. Foto klinis ekstraoral dengan kesan pipi kiri yang datar 


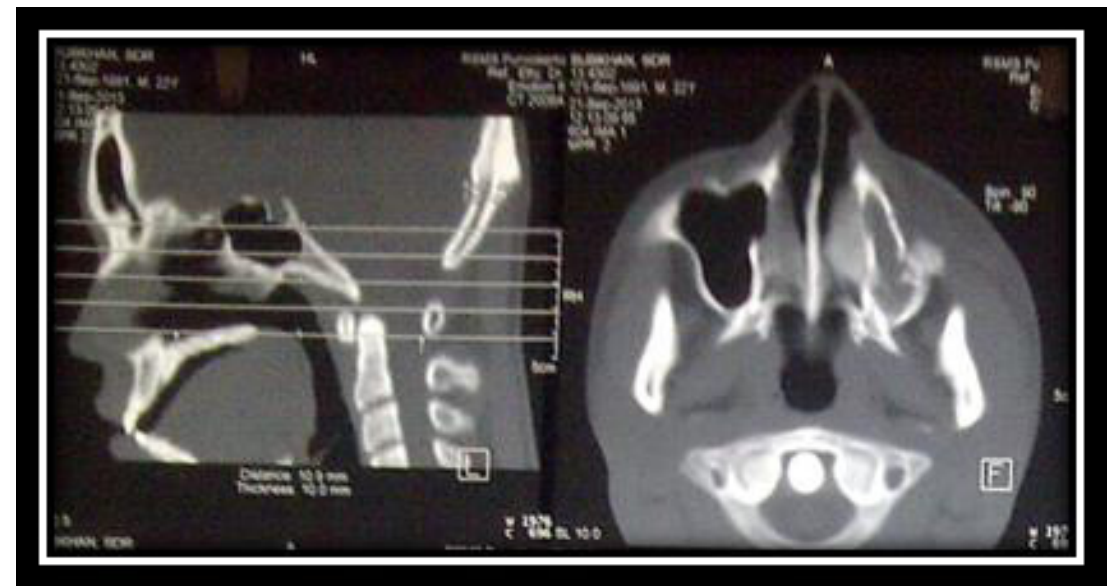

Gambar 3. Rontgen CT Scan axial

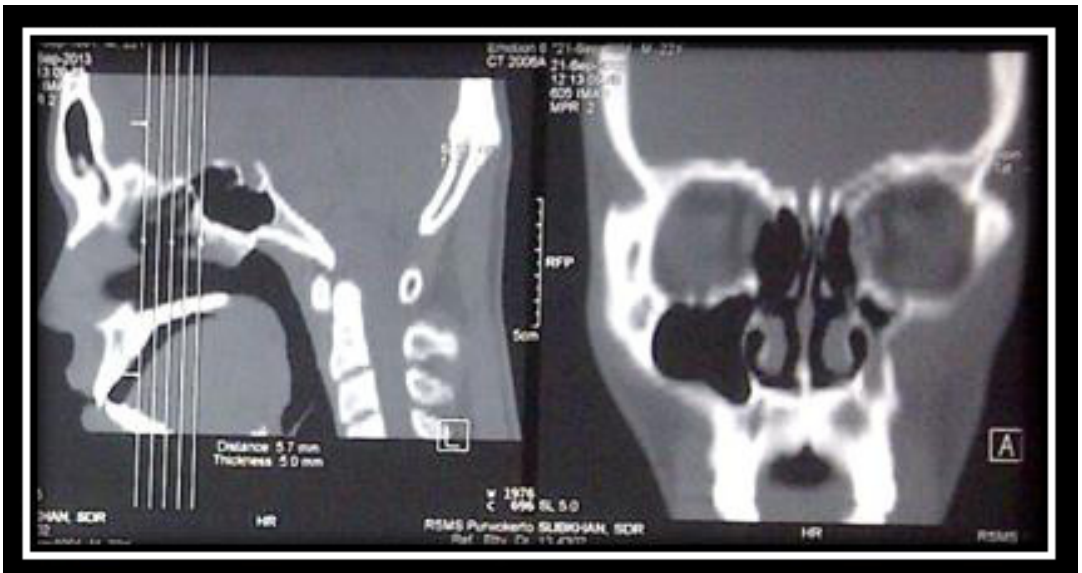

Gambar 4. Rontgen CT Scan Koronal
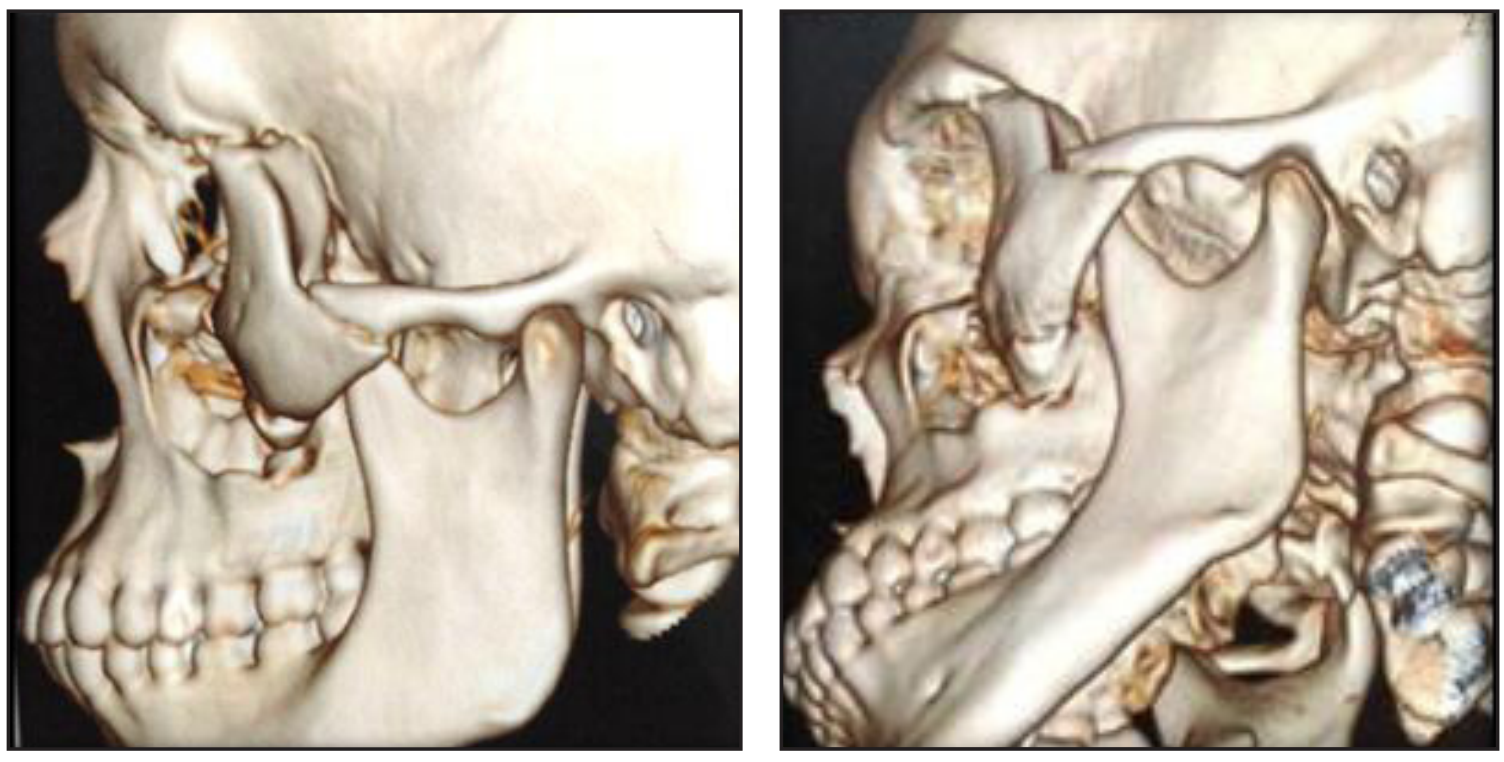

Gambar 5. Rontgen 3D CT Scan 
Akses bedah dari ekstraoral dengan insisi di infraorbita dilakukan dengan scalpel 15, diseksi hingga daerah infraorbital rim sinistra. Debridement garis fraktur di infraorbital rim dari jaringan granulasi dan kalus, ditemukan defek 5-7 mm berupa fraktur comminuted terbagi dalam dua serpihan tulang yang terpisah dari infraorbital rim. Akses bedah intraoral dengan insisi paramarginal regio 21-27 kemudian dilanjutkan dengan diseksi hingga tampak fraktur comminuted dinding sinus maksilaris sinistra yang mengalami displacement.

Reposisi fragmen tulang zigoma buttres dilakukan dari intraoral dengan elevator Elle (Gambar 7), bersamaan dengan itu dilakukan pemasangan skinhook pada daerah insisi infraorbita untuk melihat proses reposisi infraorbital rim

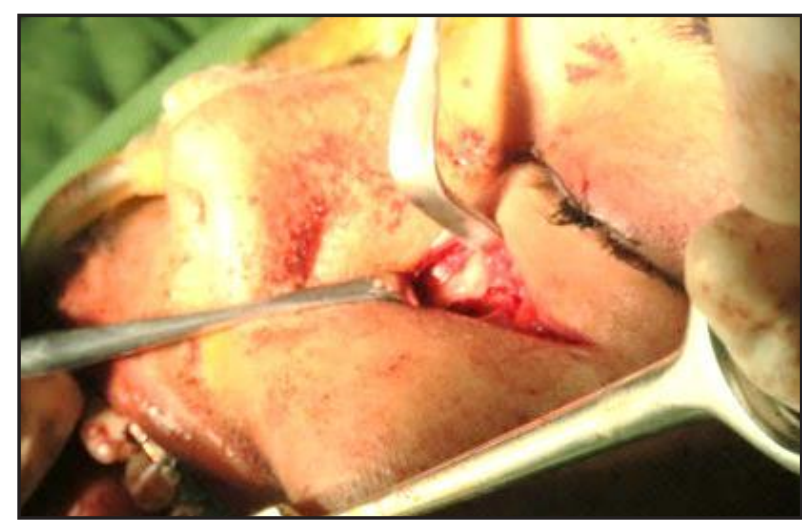

Gambar 6. Hasil reposisi fraktur infraorbita rim sinistra

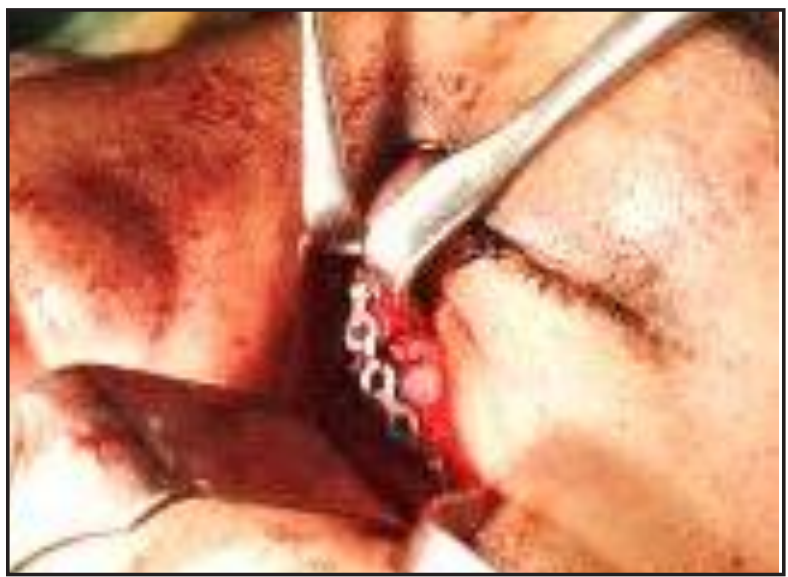

Gambar 8. Miniplate osteosynthesis (Mid face plate) $1.6 \mathrm{~mm}$ semilunar 10 holes pada infra orbital rim
(Gambar 6). Tahap berikutnya adalah pengepasan plate osteosynthesis infraorbita sinistra. Plate yang digunakan adalah miniplate $1.6 \mathrm{~mm}$ (midface plate) dengan bentuk plate semilunar 10 holes. Plate diadaptasikan mengikuti infraorbital rim dengan posisi kurang lebih $3-5 \mathrm{~mm}$ di bawah orbital rim. Screw menggunakan tipe $1.6 \mathrm{~mm}$ midfaceauto drive screw panjang $5 \mathrm{~mm}$. Total digunakan 6 screw pada daerah fraktur infraorbital rim (Gambar 8). Rekonstruksi fragmen tulang comminuted infraorbital rim dilakukan dengan menyusun dua buah fragmen tulang membentuk infraorbital rim. Fragmen dibuat dua lubang kecil dengan bur fissure kecil kemudian melalui dua lubang kecil tersebut fragmen tulang difiksasi dengan benang synthetic resorbable 4.0 (Gambar 8). Setelah terfiksasi sempurna, dimulai

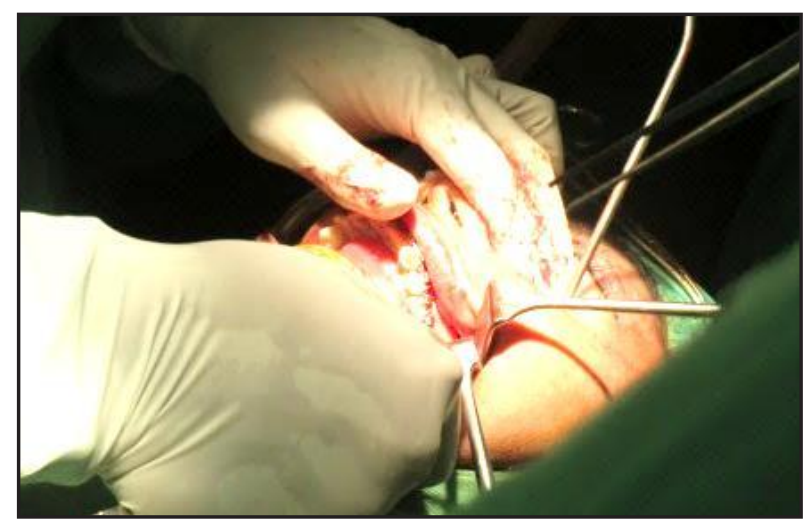

Gambar 7. Reposisi fraktur ZMC dengan Elle elevator

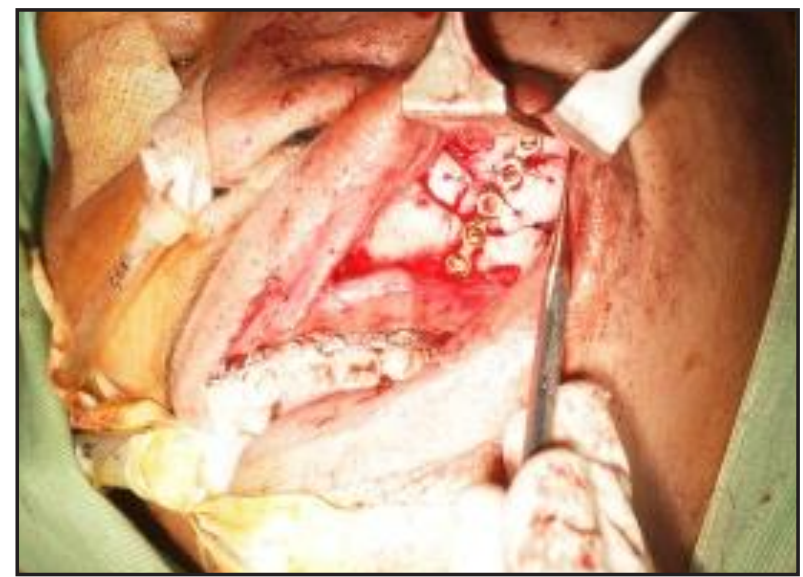

Gambar 9. Miniplate $2 \mathrm{~mm}$ stright 8 holes pada maksila 
tahap pemasangan miniplate osteosythesis intraoral pada zigoma buttres sinistra.

Plate yang digunakan untuk intra oral adalah stright miniplate $2 \mathrm{~mm} 6$ holes yang diadaptasikan mengikuti permukaan dinding sinus yang masih stabil ke zigoma buttres di arah superiornya. Terpasang 4 screws miniplate $2 \mathrm{~mm}$ dengan panjang $5 \mathrm{~mm}$ (Gambar 9). Penjahitan ekstraoral dengan penjahitan subkutan dengan synthetic resorbable 4.0 dan penjahitan kutan dengan benang nilon 5.0 teknik interupted. Penjahitan intraoral dengan benang synthetic resorbable 4.0 pada lapisan submukosa dan mukosa bukal sinistra.

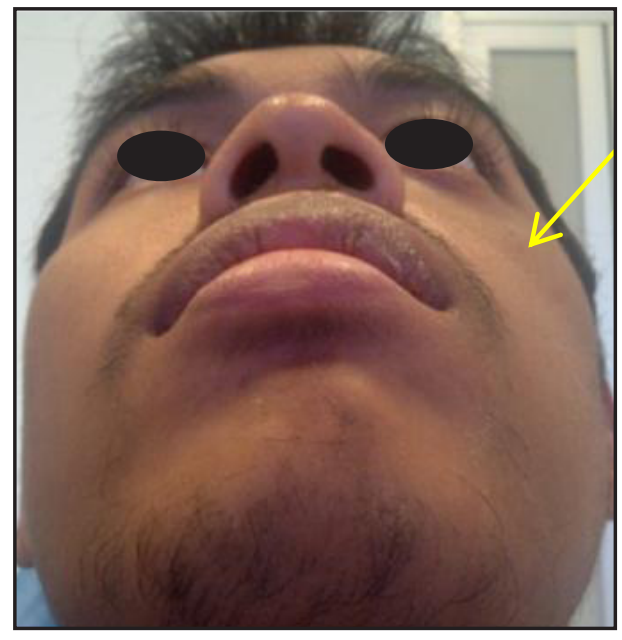

(A)
Pada hari ke lima pasca operasi pasien dipulangkan saat hasil evaluasi kondisi umum dan vital signs stabil, luka operasi membaik, nyeri, mual, muntah terkontrol, mampu mobilisasi, diet cair via oral dan mampu BAB/BAK. Medikasi yang diberikan adalah antibiotik, analgetik dan ruboransia. Hasil kontrol pasien setelah 14 hari pasca operasi tampak kesan tulang pipi kiri prominen simetris dengan pipi kanan dan perasaan tebal di pipi kiri berangsur-angsur berkurang (Gambar 10). Dilakukan pemeriksaan plain radigrafi panoramik (Gambar 11.) pasca operasi di dapat orientasi miniplate osteosynthesis baik dan dapat diterima.

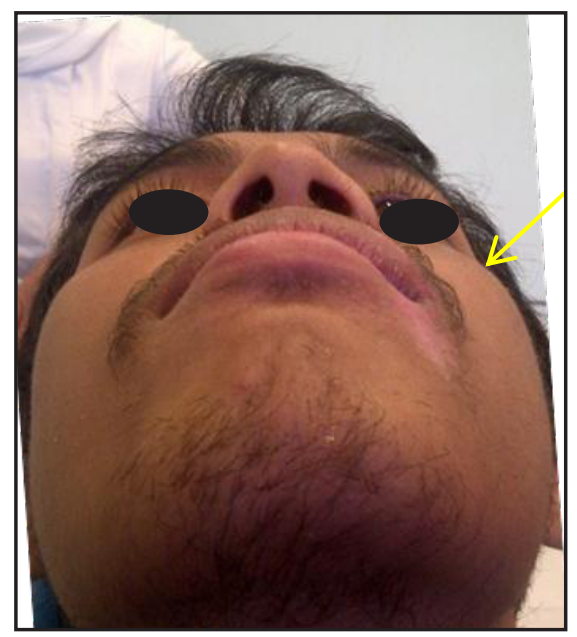

(B)

Gambar 10. Foto preoperasi (A) dan Foto pasca operasi hari ke 14 (B) memperlihatkan pipi kiri kembali prominen

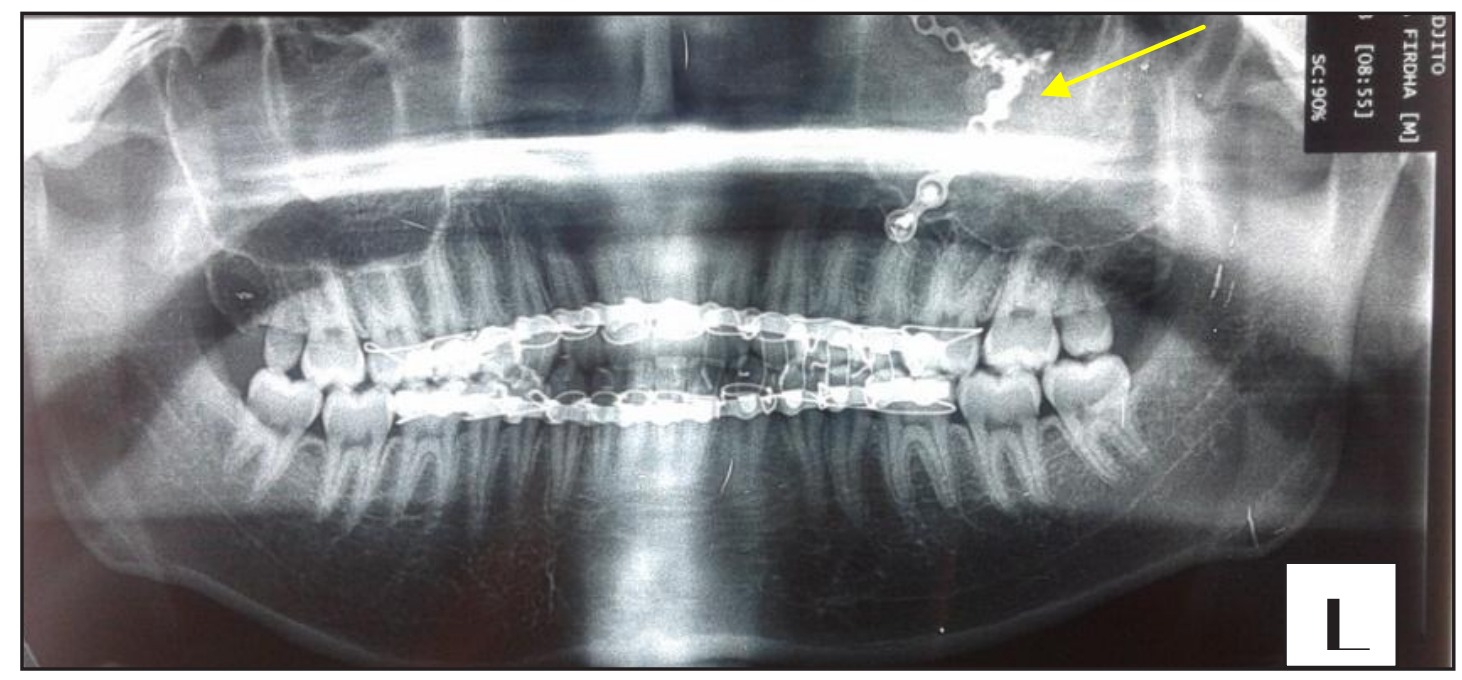

Gambar 11. Rontgen Panoramik memperlihatkan orientasi posisi miniplate 


\section{DISKUSI}

Pasien dalam laporan kasus ini mengalami fraktur kompleks zigomatiko-maksila. Benturan pada malar eminensia mendorong os.zigoma ke inferior, mendesak sinus maksilaris sehingga terjadi fraktur comminuted dinding sinus maksilaris sisi bukal. Riwayat perdarahan hidung sebelah kiri pasca kecelakaan karena adanya hematosinus. Fraktur pada sutura zigomatikomaksilaris yang tampak pada infraorbital rim sinistra tampak pada pipi kiri pasien yang menjadi datar pasca kecelakaan. Mekanisme fraktur tulang zigoma terjadi karena benturan langsung yang biasanya mengenai bagian yang prominen pada wajah seperti eminensia malar menyebabkan rusaknya struktur tulang wajah yang lebih lemah daripada zigoma yaitu ke maksila, arkus zigomatikus, prosesus frontalis dan sutura zigomatikomaksilaris. ${ }^{6}$ Fraktur kompleks zigomatik disebabkan oleh benturan tumpul rendah energi pada lateral orbital rim dan eminensia malar pada saat kecelakaan kendaraan bermotor atau kekerasan fisik. Fraktur ini adalah tersering setelah fraktur nasal pada cedera wajah dan lebih sering pada laki-laki usia 20-40 tahun. $^{7}$

Etiologi fraktur kompleks zigomatikomaksilaris pada kasus ini adalah karena trauma kecelakaan kendaraan bermotor roda dua. Dalam literatur selain kecelakaan lalu lintas, etiologi pada trauma wajah dapat meliputi tindakan kekerasan, olahraga, terjatuh, injuri karena perang, luka tembak dan adanya kecelakaan kerja. Dua etiologi yang dominan adalah kecelakaan lalu lintas dan tindak kekerasan. $^{8}$

Tanda klinis khas fraktur komplek zigoma yang muncul pada kasus ini adalah kondisi malar eminensia yang menjadi datar. Hal tersebut terjadi pada 70-86 \% kasus fraktur komplek zigoma. ${ }^{9}$ Tanda khas lain dari fraktur komplek zigoma yang muncul dalam kasus ini adalah parestesi nervus infraorbita. Insidensi gangguan sensoris nervus infraorbita akibat trauma os. zigoma adalah $18-83 \% .^{10}$ Beberapa temuan fisik pada kasus fraktur kompleks zigomatikomaksila yaitu meliputi diplopia, trismus, nyeri periorbital, edema dan ekimosis periorbita, hemoragi subkonjungtiva, hilangnya prominen pada malar, tulang irreguler pada infraorbital rim dan zigomatikomaksilari buttres, hanya diplopia, trismus dan edema periorbita tidak dijumpai pada kasus ini. ${ }^{11}$

Pemeriksaan neurosensoris klinis pada distribusi nervus infraorbita sinistra dengan light touch dan pin prick menunjukkan adanya injuri ringan saraf perifer yaitu neuropraksia (klasifikasi Seddon) atau cedera saraf tipe satu (klasifikasi Sunderland). ${ }^{12,13}$ Insidensi gangguan sensoris jangka panjang pada fraktur kompleks zigoma yang melibatkan cedera nervus infraorbita dilaporkan mencapai $45 \% .^{7}$ Prognosis untuk cedera saraf tipe satu atau neuropraksia adalah baik, dimana akan terjadi remielinisasi dari segmen yang terlibat dan diperkirakan penyembuhan akan terjadi dalam 2-12 minggu. ${ }^{19}$

Penegakan diagnosis pada kasus fraktur kompleks zigomatikomaksila meliputi beberapa tahapan yaitu pengumpulan riwayat medik pasien, pemeriksaan klinis dan pemeriksaan radiologis. Pemeriksaan radiologis awal pada kasus ini dengan plain radiografi panoramik kemudian dilakukan pemeriksaan $C T$ scan axial dan koronal pada regio wajah serta dilanjutkan dengan pemeriksaan 3D CT untuk visualisasi tiga dimensi daerah fraktur wajah. Setiap pasien dengan fraktur sepertiga tengah wajah direkomendasikan dilakukan pemeriksaan CT scan pada arah axial dan koronal. Plain radiografi menyediakan informasi yang terbatas dan biasanya tidak mencukupi untuk perencanaan preoperatif. ${ }^{7}$ Umumnya pada injuri wajah, pencitraan dengan $C T$ scan sudah cukup untuk diagnosis dan menentukan perawatan. 3D CT merupakan media yang lebih dapat diterima ahli bedah dengan akurasi interpretasi lebih besar dibandingkan CT scan axial konvensional. ${ }^{10}$

Tindakan open reduction internal fixation (ORIF) pada kasus ini dilakukan lebih dari tiga minggu pasca trauma. Operator mengalami kendala adanya jaringan fibrous saat reduksi os. zigomatikum dan rekontruksi pada fraktur comminuted yang terjadi pada infraorbital rim dan dinding sinus maksila sinistra. Menurut literatur, reduksi fraktur kompleks zygmoatik menjadi lebih sulit dengan berjalannya waktu, jika diperlukan operasi dapat ditunda hingga 10 hari untuk menunggu edema menghilang. Setelah dua minggu tulang yang mengalami displace menjadi terikat dengan jaringan fibrous, tetapi lebih 
baik dilakukan koreksi primer daripada menetapkan rekonstruksi sekunder, reduksi dalam prakteknya dapat dicapai hingga 6 minggu setelah trauma dan kadang lebih dari itu. ${ }^{2}$ Reduksi tulang wajah harus ditunda jika pasien mempunyai injuri yang harus diutamakan dan pada kondisi mengancam jiwa. ${ }^{5}$

Indikasi dilakukan prosedur ORIF pada kasus ini adalah adanya os. zigoma yang mengalami depressed ke arah posterior dan inferior, os. zigoma tidak stabil karena melibatkan tiga daerah fraktur yaitu infraorbital rim dari sutura zigomatikomaksila, sutura zigomatikofrontalis dan sutura zigomatikotemporalis. Fraktur dengan displace terjadi pada infraorbital rim dan sutura zigomatikomaksila, fraktur disertai fraktur comminuted regio dinding sinus maksilaris sinistra dan infraorbital rim sinistra. Indikasi lain adalah untuk mengembalikan fungsi estetik.' Westernmark dkk. ${ }^{17}$ dalam penelitiannya menyarankan untuk melakukan reduksi fraktur dan pemasangan fiksasi rigid pada infraorbiatal rim untuk menurunkan insidensi gangguan sensoris nervus infraorbita. Peneliti lain merekomendasikan tindakan fiksasi pada fraktur zigoma yang tidak stabil hubungannya dengan pemulihan sensoris nervus infraorbita. Mereka menyarankan menggunakan miniplate osteosynthesis yang dibandingkan fiksasi kawat dan fiksasi pada infraorbital rim memberikan prognosis yang lebih baik untuk pemulihan sempurna fungsi nervus infraorbita dibandingakan hanya dilakukan reposisi dengan atau tanpa menggunakan fiksasi kawat Kirschner. ${ }^{16}$. Peneliti sebelumnya sependapat bahwa penggunaan miniplate osteosynthesis disarankan pada kasus fraktur zigoma tidak stabil dengan displacement karena dalam penelitiannya ditemui masih adanya $50 \%$ defisit neurologis nervus infraorbita pada fiksasi dengan kawat sedangkan pada penggunaan miniplate defisit neurologis hanya mencapai 22,1\%." Pada kasus ini telah dilakukan reduksi dan fiksasi fraktur pada infraorbital rim dengan miniplate osteosynthesis (mid face plate 1.6) dengan enam buah crews $5 \mathrm{~mm}$. Pada kontrol hari ke 14 sensasi tebal di pipi dirasakan mulai berkurang yang menandakan telah terjadi dekompresi serabut saraf nervus infraorbita sinistra setelah dilakukan reduksi dan fiksasi pada fraktur regio infraorbita sinistra. Hal ini seperti yang disampaikan peneliti lain bahwa penatalaksaan kasus fraktur kompleks zigomatikomaksilaris unilateral menggunakan sistem miniplatedan crews $1,5 \mathrm{~mm}$ terbukti efektif, menunjukkan hasil estetis baik dan rata-rata komplikasi yang rendah.?

\section{KESIMPULAN}

Telah dilaporkan kasus reposisi dan fiksasi dengan menggunakan miniplate osteosynthesis pada kasus fraktur komplek zigomatikomaksilaris sinistra. Prosedur ORIF yang dilakukan dapat memulihkan deformitas wajah pada bagian sepertiga tengah wajah dengan hasil malar eminensia kembali prominen dan diperoleh kondisi dekompresi nervus infraorbita sinistra sehingga mendukung proses pemulihan pada cedera saraf perifer neuropraksia nervus tersebut dengan hasil hilangnya jejas persisten dan prognosis baik.

\section{DAFTAR PUSTAKA}

1. Banks P, Brown A. Fracture of facial skeleton. London: MPG Books Ltd; 2001. H.132

2. Rana M, Warraich R, Tahir S, lqbal A, Constantin VS, Eckardt AM, Gellrich NC. Surgical treatment of zygomatic bone fracture using two points fixation versus three point fixation-a randomised prospective clinical trial. Trials. 2012; 13: 36.

3. Banks P. Fraktur sepertiga tengah skeleton fasial menurut Kelley. Edisi 4 terj. Yogyakarta: Gadjah Mada University Press; 1992. H. 39-51

4. Thaller SR, Mc Donald WS. Facial trauma. New York: Marcel Dekker; 2004. H. 251.

5. Manson PN. Fracture of the zygoma. In: Booth PW, Dchendel SA, Hausamen JE. Maxillofacial surgery, Ed 2. St. Louis: Churchill Livingstone Elsevier. 2007. H. 122.

6. Budihardja AS, Masykur R. Fraktur wajah, trauma oral dan maksilofasial. Jakarta: Penerbit Buku Kedokteran EGC; 2012. H.144-152,165

7. Dolan RW. Zygomatic complex and internal orbital fractures. In: Dolan RW. Facial plastic reconstruction , and trauma surgery. New York: Marcel Dekker; 2004. 
8. Thomas DW, Hill CM. Etiology and chaging patterns of maxillofacial trauma. In: Boothb PW, Dchendel SA, Hausamen JE. Maxillofacial surgery. Ed 2. St. Louis: Churchill Livingstone Elsevier; 2007. H. 3.

9. Ellis E, El-Attar A, Moos KF. An analysis of 2,067 cases of zigomatico-orbital fracture. J oral Maxillofac Surg. 1985; 43: 428.

10. Bailey JS, Goldwasser MS. Management of zygomatic complex fracture, In: Miloro M. Peterson's principles of oral and maxillofacial surgery. 2nd Ed. London: BC Deker Inc; 2004. H. 446,457.

11. Laskin DM, Abubaker AO. Decision making in oral maxillofacial surgery. Chicago: Quintessence Publishing Co Inc; 2007. H. 63-64.

12. Labanc JP. Maxillofacial nerve injuries: evaluation, classification, and management. In: Fonsesca RJ, Walker RV, Betts NJ, Barber HD. Oral and Maxillofacial Trauma Vol 2. Ed 2. Philadelphia: WB Saunders company; 1997. H. 913-924.

13. Quan D, Bird SJ, Nerve conductions studies and electromyography in the evaluation of peripheral nerve injuries. The university of pennsilvania orthopaedic journal. 1999; 12 :45-51.
15. Westermark A, Jensen J, Pederson SS. Zygomati fracture and infraorbital nerve distrubance. Miniplate osteosynthesis vs other treatment modalities. Oral Surg Oral Diagn. 1992; 3: 27

16. Vriens JP, Mooks KF. Morbidity of the infraorbital nerve following orbitozygomatic complex fractures. J Craniomaxillofac Surg. Des 1995; 23(6): 363.

17. Man DK, Bax WA. The influence of the mode of treatment of zygomatic bone fracture on the healing process of the infraorbital nerve, Br J Oral Maxillofac Surg. Okt 1998; 26 (5): 419.

18. Young CC, editor. Facial fractures, mescape reference. WebMD LLC; 2011 Sep, Website: http://emedicine. medscape.com/article/84613-overview diunduh pada 1 Desember 2012

19. Hasse PN, Gealt WC, Pereira CCS, Cordazzi LF, Filho OM, Junior IRG, Clinical and $r$ a d i o g r a p h i c evaluation of surgical treatment of zygomatic fracture using 1.5 miniplate system. Open Journal of stomatology. 2011; 1, 172-178. 